\title{
Prostate Cancer Pathologic TNM Finding v8
}

National Cancer Institute

\section{Source}

National Cancer Institute. Prostate Cancer Pathologic TNM Finding v8. NCI Thesaurus.

Code C140145.

A pathologic finding about one or more characteristics of prostate cancer, following the rules of the TNM AJCC V8 classification system. 